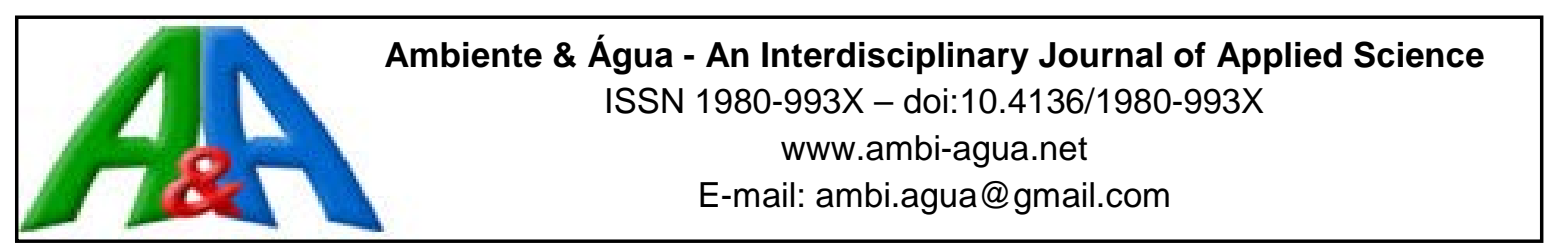

\title{
Biogas originated from residual biomass in ecosystem services
}

ARTICLES doi:10.4136/ambi-agua.2214

Received: 22 Nov. 2017; Accepted: 17 May 2018

\author{
Gladis Maria Backes Bühring*; Vicente Celestino Pires Silveira \\ Universidade Federal de Santa Maria (UFSM), Santa Maria, RS, Brasil \\ Departamento de Educação Agrícola e Extensão Rural (DEAER) \\ E-mail: gmbackes@gmail.com, vcpsilveira@gmail.com \\ *Corresponding author
}

\begin{abstract}
Human demand for the provisioning services of the ecosystem has been rising and shows the existence of trade-offs in their generation. Brazil is a great producer of agricultural commodities and animal protein, which generates a large amount of residual biomass throughout the production process, especially animal highly polluting waste concentrated in small areas. Ecosystems provide a wide range of services that are of fundamental importance to the well-being, health, subsistence and survival of human beings. The impacts of the waste generated by confined animals can degrade the ecosystem and reduce the services it can supply. Using waste to generate biogas does not require direct resources from the ecosystems to generate energy. In this context, it is an energy product classified as a provisioning service and, at the same time, an ecosystem regulating service, as it mitigates undesirable effects in the environment. The main goal of the classification of biogas as an ecosystem service is to explore its contributions to the ecosystem and to human well-being.
\end{abstract}

Keywords: ecosystem services, renewable energy, residual biomass.

\section{Biogás oriundo da biomassa residual nos serviços ecossistêmicos}

\section{RESUMO}

A demanda humana pelos serviços de provisão do ecossistema vem crescendo, e mostram a existência de trade-offs na sua geração. O Brasil é um grande produtor de commodities agrícolas e proteína animal, mas que gera um grande volume de biomassa residual ao longo do processo produtivo, com destaque para os dejetos de animais concentrados em pequenas áreas e com alto grau poluidor. Os ecossistemas fornecem uma gama de serviços que são de fundamental importância para o bem-estar, saúde, meios de subsistência e sobrevivência aos seres humanos. Os impactos da produção de animais confinados podem degradar o ecossistema e reduzir os serviços que o ecossistema pode fornecer. O aproveitamento dos dejetos para gerar biogás não utiliza recursos diretos dos serviços dos ecossistemas para gerar energia, e neste contexto é um produto energético classificado como um serviço de provisão e ao mesmo tempo um serviço ecossistêmico de regulação, na medida em que exerce a mitigação de efeitos indesejados no ambiente. A classificação do biogás nos serviços ecossistêmicos tem como finalidade principal abordar as contribuições ao ecossistema e para o bem-estar humano.

Palavras-chave: biomassa residual, energia renovável, serviços ecossistêmicos. 


\section{INTRODUCTION}

Ecosystems provide a wide range of services that are of fundamental importance to the well-being, health, subsistence and survival of human beings. The impacts of the production of concentrated residues can degrade the ecosystem and reduce the services it can provide. Ecosystem services can be defined as the direct and indirect contributions of structures and functions of ecosystems, in combination with other factors of production, to human well-being (Burkhard et al., 2012).

Agricultural production interacts with the environment through use of resources and production of residues and through its volume and composition, which can contain high levels of organic matter, nutrients and microorganisms with potential for pollution of water, air and soil. The leaching of nutrients, especially nitrogen $(\mathrm{N})$ and phosphorus $(\mathrm{P})$, evaporation of ammonia $\left(\mathrm{NH}_{3}\right)$ and contamination by pathogens are some of the biggest threats (Holm-Nielsen et al., 2009). The volume of animal excrement is an environmental challenge due to its huge quantity and high risk of water and air pollution (Fernandez-Lopez et al., 2016; Oudart et al., 2015). The emission of $\mathrm{NH}_{3}$, greenhouse gases and odors is a concern related to excrement disposal (Loyon, 2017) and, in addition, they are a source of pathogenic agents and nitrates $\left(\mathrm{NO}_{3}{ }^{-}\right)$that may affect the surface waters and groundwaters (Millner et al., 2014).

With a growing demand for food production, agricultural production is increasingly causing impacts on the environment, with a larger scale of animal production in small spaces and more waste production, which represents a considerable threat of pollution leading to more pressure on the environment in these areas. This brings us to the challenge of integrating ecosystem services with the management of the residual biomass generated by confined animals. When managed improperly, this may adversely impact the environment.

Managing the environment requires us to understand how changes in demand, production and offer of products and energy affect ecosystem services. The products and services generated in an economy are associated with unavoidable environmental consequences, even nonintentional (Baumgärtner et al., 2001), and the environmental impacts may occur in different stages of the life cycles of these products and services (Tukker and Jansen, 2006). Therefore, it is important to understand the impact of animal waste on the environment and how it affects local ecosystem services. It is also important to understand its interactions and multiple effects, and to explore alternatives to reduce these impacts on the environment without compromising the delivery of other ecosystem services and risk generating trade-offs.

The use of biomass for energy production is one of the most promising alternative sources of sustainable and renewable energy (Cherubini and Strømman, 2011); its production and usage therefore assumes great economic and environmental importance. In comparison to other biofuels, biogas is versatile and flexible, and can be produced from different types of feedstock, like the ones provided by the agricultural sector and from other flows of organic residues from society in general. In the rural environment, the biggest resource is represented by waste of animals confined in production units, such as swine, birds and bovines.

Within the context of ecosystem services and with the intention of using renewable and sustainable energy, biogas is a practical approach to reduce the local energy deficit and mitigate problems of environmental contamination. Thus, biogas generated from animal waste can be considered an energy product with a provisioning service function and, at the same time, it functions as a regulating service because it mitigates undesirable effects in the environment. The goal of this paper is therefore to describe how biogas generated from of animal waste fits in the concept of ecosystem services of provision and regulation.

\subsection{Residual biomass and biogas}

Having a safe supply of energy is crucial for the well-being of people and the economy in the world (Olson-Hazboun et al., 2016). Biomass represents a renewable and abundant source 
of energy and has the potential to become a global font of resources in the $21^{\text {st }}$ century. The current energy supply depends on fossil sources, which are non-renewable and limited. Renewable energy sources are not subject to depletion and are beneficial to the environment. Reusing waste is a great opportunity to generate renewable energy in the form of biogas, as it represents an attractive trade-off in terms of reduction of the impact in the development and use of renewable energy.

It is likely that biomass, because it is a cleaner energy, will become an appealing option to reduce emissions of greenhouse gases (Junfeng and Runqing, 2003) The potential for reduction in the emission of greenhouse gases is one of the main benefits of the use of biomass in the production of energy and the use of biodigesters represents a unique platform for recycling nutrients, thus closing the cycles of important resources which, if not controlled adequately, may cause negative environmental impacts (Holm-Nielsen et al., 2009).

Sustainability is of fundamental importance in the use of biomass as feedstock for production of energy. Its use can promote a more-sustainable agriculture, since promoting sustainability in productive ecosystems can lead to synergy between production and maintenance of ecosystem services, resulting in the production of food, fibers and energy, given that agricultural productive systems are also a source of ecosystem services (Swinton et al., 2007).

Managing residues is a basic component of economic and environmental sustainability in the production of confined animals, especially in relation to waste. At the scale of the rural property, the most usual way of handling it is through use in the soil, which produces significant atmospheric emissions of greenhouse gases, consumes fossil energy resources and can result in the accumulation of nutrients in the soil (Aguirre-Villegas et al., 2014).

The amount of waste produced per year in Brazil corresponds to a considerable volume of residual biomass. Highlighting the production of waste from swine breeding, it is possible to include waste from broiler chickens, laying birds, milk cows and beef cattle, which totals $1,703,773,970$ t year $^{-1}$ of waste (IPEA, 2012). In swine breeding the main problem is the volume and the characteristics of the waste, which is in liquid form and with high organic rate; with cattle, the biggest impact is the system of breeding (extensive or confined), because to generate biogas it is necessary to pick up the waste, which is only plausible in confined breeding. The waste produced by aviculture is of great volume and is usually concentrated in small areas.

Using the waste from these animals can promote a cleaner environment and provide energy as a product with economic potential. Treatment of residual biomass can be made through anaerobic digestion with the production of biogas (Qiao et al., 2011). Anaerobic digestion is a microbiological process in which organic matter is degraded in the absence of oxygen, which therefore decreases the organic load, resulting in biogas. In the specific case of animal waste, the stabilized suspension after anaerobic digestion, the digestate, can be used as a fertilizer and consists of essential nutrients for the growth of plants (Mata-Alvarez et al., 2000).

From the perspective of the production of biogas originated from residual biomass, agricultural production goes from a productive role to a multifunctional one, considered in a systemic approach capable of producing food and meeting the new needs of consumers, offering services like energy, landscape, tourism, etc. Energy production from residues represents this concept, in search of environmental balance in production activities; it integrates animal and energy production from renewable sources, and in the case of biogas, contributes to the treatment of potentially polluting residues.

\subsection{Ecosystem services}

The term "ecosystem services" describes the benefits we obtain from ecosystems. According to Costanza et al. (1997), goods from the ecosystem (like food) and services (like assimilation of residues) represent the benefits enjoyed by human populations, directly or 
indirectly from the functions of the ecosystem. People benefit from ecosystem services which are, among others, nutrition, access to air and water, health, safety, leisure (Maes et al., 2016). The benefits from ecosystem services potentially influence several elements of human wellbeing, such as basic human necessities, economic necessities, environmental necessities and subjective happiness (Summers et al., 2012). Human well-being is incorporated into the concept and the definition of ecosystem services, as there are no services if human beings do not benefit from either the functions or the processes that generate them (Kandziora et al., 2013). Therefore, assuming human well-being strongly depends on services provided by well-functioning ecosystems, changes in the operation of any system may have direct and indirect effects on it.

Impact and human management strongly affect ecosystems, including their processes and functions (Gissi et al., 2016). Nowadays, the demands for ecosystem services created by human activity surpass what is available, which is the capacity of the ecosystems to mitigate pollutants and provide necessary natural goods, affecting the operation of ecosystem services (Steffen et al., 2015). Changes in human needs result in modifications of human demands. This reflects on the services provided by ecosystems, resulting in adverse consequences, as it is fundamental to ensure the provision of ecosystem services in quantity and quality and maintained at adequate levels. The challenge is to manage the trade-offs between immediate human needs and the maintenance of the capacity of the ecosystem to provide goods and services.

The basis definition of CICES (Common International Classification of Ecosystem Services) is that ecosystem services are the contributions of the ecosystems (natural or modified) that directly or indirectly affect human well-being; the goods and benefits from ecosystems are what people create or what derives from ecosystem services and can be referred to as "products" (Haines-Young and Potschin, 2013). According to CICES, ecosystem services are "final" because they are the results from ecosystems that most directly affect the well-being of people, giving the idea that services lead to changes in human well-being because of the benefit they generate. In the context of CICES, the classification is according to services, not benefits (Haines-Young and Potschin, 2013).

We depend on the provisioning of ecosystem services. However, continuous interference in the dynamics of ecosystems is altering all of these services. The use of indicators can provide information that help in the understanding and managing activities that potentially interfere in the ecosystems, such as the residues produced by confined animals. Thus, ecosystem services provide groups of indicators that include descriptive aspects and evaluation items (Reyers et al., 2010). The indicators also help in understanding more complex realities and, for this reason, are instruments of communication that assist in reducing the complexity of humanenvironmental systems (Kandziora et al. 2013).

\section{MATERIALS AND METHODS}

This article used CICES as a basis to classify the ecosystem services of biogas originated from residual biomass from the waste of confined animals. According to Haines-Young and Potschin (2013), CICES are organized within three main groups of services (regulating, provisioning and cultural services), including more detailed definitions and suggestions of potential indicators. The indicators may refer to actions that cause environmental changes, to the exposure of an environmental component to stress, to environmental conditions, to effects caused by certain impacts, or to social responses to environmental changes (Braband et al., 2003). The CICES classification was adopted because it provides a method to classify ecosystem services in a hierarchical structure, with each level providing a more detailed description of the ecosystem service being considered.

Provisioning services are related to the nutrition, materials and energy of living systems, including tangible products from the ecosystems that human beings use, which can be 
commercialized and consumed or used directly (Haines-Young and Potschin, 2013). Regulating services are the ways in which living organisms can mediate or moderate the environment that affects human performance (Haines-Young and Potschin, 2013). These are services with less tangible benefits, resulting from ecosystems when abiotic and biotic factors are controlled and/or modified (Haines-Young and Potschin, 2010).

Cultural services are related to non-material and normally non-consumable aspects of the ecosystems that affect the physical and mental states of people (Haines-Young and Potschin, 2013), referring to intangible benefits that people receive from ecosystems in the form of nonmaterial, spiritual, religious, inspiring and educational experiences (Kandziora et al., 2013).

There was also a proposal of potential indicators for the ecosystem services of biogas. That is, indicators were used to show the quantity and types of services specific to biogas, considering primarily a local scale in a rural property. An indicator for an ecosystem service is information that communicates the characteristics and tendencies of the ecosystem services, making it possible, for example, for those who propose policies to understand the conditions, tendencies and the rate of change in the ecosystem services (Layke et al., 2012).

The hierarchical structure of CICES also allows evaluations to be adapted to specific needs, at the same time allowing the possibility of comparisons, referring specifically to final results or products of the ecosystems. CICES uses the triple division consisting of provisioning services, regulating services and cultural services. To sum it up, provisioning services are related to materials, while regulating services relate to the intervention of aspects of the environment that affect the well-being of people, while cultural services include material and intellectual benefits.

\section{RESULTS AND DISCUSSION}

In order to mitigate climate change and increase energy safety, the search for renewable energy has been growing in the past years (McBride et al., 2011). However, the expansion of renewable energy can be considered controversial in terms of competition for land use and implies in trade-offs (Jackson, 2011), like intensification of use of land and competition with food production caused by the production of biofuels, leading to the need to systematically analyze advantages and disadvantages of renewable energy to find a better solution (Silveira et al., 2017).

Sustainability is of great importance to the production of energy and, for it to be considered sustainable, it must not compete with other chains of production, distribution or use of food. Land dedicated to the production of food should also not compete with the land used to produce energy (Arodudu et al., 2013). For this reason, in order not to represent a risk for food and environmental safety, the increase of production of renewable energy must involve a selection of feedstock like residual biomass, because biomass must not consume more carbon (C) from fossil fuels than it can remove (Whalen et al., 2017). In this sense, it is important to use biomass that does not compete with food production, but complements it in terms of ecosystem services and its contribution to human well-being (Bühring and Silveira, 2016).

As put by Hastik et al. (2015), the concept of ecosystem service seems to represent an appropriate approach to evaluate environmental matters associated with the expansion of the exploration of renewable energies like biogas. Most of the impacts on ecosystem services are determined by rising demand resulting in the intensified use of land, which does not happen with biogas originated from residual biomass, such as animal waste.

The energy of the biogas produced from residual biomass, which used to be considered worthless and having a pollutant organic load, does not raise the pressure on the usage of land and water. These systems of biogas production can make animal production more sustainable and avoid dilemmas between food and fuels, which occur with other biofuels, turning biogas 
into a differentiated energy source. As it gives energy, biogas can be classified as a provisioning ecosystem service, according to Table 1; it can generate compensations by providing ecosystem services (energy) and its adoption can benefit the whole society, because it depends on the ecosystem services provided. When the feedstock is made of residues, one can understand that the production of biogas acts as a regulating service, according to Table 1, because it uses residual biomass that reduces the organic load of waste and the emission of greenhouse effect gases in the environment. This way, the impacts caused by residues of animal production can, according to Müller and Burkhard (2012), be understood as changes in the provisioning of goods and ecosystem services and in the socioeconomic system. Therefore, the use of these residues in the production of energy can elevate the status of biogas to ecosystem service.

Agricultural production systems can satisfy the growing demand for renewable energy providing adequate biomass for production of energy, in which high volumes of waste need to be managed in a sustainable way, optimizing the use of nutrients and energy potential, while at the same time minimizing negative impacts in the environment. The interest in energy derived from biomass is based on the premise that it can reduce external dependence on energy supply, develop a renewable base and also reduce greenhouse gas emissions, which contribute to climate change. Due to their growing importance, energy sources based in biomass have been included in CICES as provisioning ecosystem services.

The classification of biogas originated from residual biomass according to CICES and a proposal of potential indicators for biogas are shown in Tables 1 and 2.

Table 1. Classification of the ecosystem services of biogas originated from residual biomass presented in the section, division, group and class levels according to CICES.

\begin{tabular}{l|llll}
\hline Ecosystem service & Section & Division & Group & Class \\
\hline & Provisioning & Energy & $\begin{array}{l}\text { Source of energy } \\
\text { from biomass }\end{array}$ & $\begin{array}{l}\text { Resources based in } \\
\text { animals }\end{array}$ \\
\cline { 2 - 5 } Biogas & $\begin{array}{l}\text { Mediation by } \\
\text { residues }\end{array}$ & $\begin{array}{l}\text { Mediation by } \\
\text { ecosystems }\end{array}$ & $\begin{array}{l}\text { Filtration, } \\
\text { capture, storage, } \\
\text { accumulation by } \\
\text { ecosystem }\end{array}$ \\
& $\begin{array}{l}\text { Regulation and } \\
\text { maintenance }\end{array}$ & $\begin{array}{l}\text { Maintenance of } \\
\text { physical, chemical } \\
\text { and biological } \\
\text { conditions }\end{array}$ & $\begin{array}{l}\text { Atmospheric } \\
\text { Composition } \\
\text { and climate } \\
\text { regulation }\end{array}$ & $\begin{array}{l}\text { Global climate } \\
\text { regulation through } \\
\text { reduction of } \\
\text { concentration of } \\
\text { greenhouse effect gases }\end{array}$ \\
\hline
\end{tabular}

The ecosystem services may be set as indicators if the goal is a relevant management communication about the recent, past or future conditions of human-environment systems (Müller and Burkhard, 2012). It is important to emphasize that the definitions and classifications of indicators, as well as ecosystem services, deeply depend on the characteristics of the investigated ecosystems and on the decision context in which they are applied (Fisher et al., 2009; Reyers et al., 2010). The classification of biogas originated from residual biomass in ecosystem services allows a general view of the potential services of the ecosystem that might be relevant in this context, especially those related to the production unit. It is important to note that it is a starting point to reflect upon functions, processes and subjacent structures and on how to reach sustainable management of the process of production of confined animals and the environment, especially locally and regionally. 
Table 2. Proposal of indicators to represent biogas in the regulatory and provisioning ecosystem services.

\begin{tabular}{|c|c|c|}
\hline & Definition & Potential indicator \\
\hline \multicolumn{3}{|c|}{ Provisioning service } \\
\hline Energy Provisioning & $\begin{array}{l}\text { Generation of energy through treatment of } \\
\text { waste by anaerobic digestion. }\end{array}$ & $\begin{array}{l}\text { Availability of waste } \\
\left(\mathrm{m}^{3} \text { year }^{-1}\right) \\
\text { Production of biogas } \\
\quad\left(\mathrm{m}^{3} \text { yearr }^{-1}\right) \\
\text { Energy per } \mathrm{m}^{3} \text { of waste } \\
(\text { Toe, } \mathrm{kWh}, \mathrm{kCal})^{\mathrm{a}}\end{array}$ \\
\hline \multicolumn{3}{|c|}{ Regulating service } \\
\hline Regulation of air quality & $\begin{array}{l}\text { Capture of odors from waste stored through } \\
\text { the treatment by anaerobic digestion }\end{array}$ & Perception of odor \\
\hline $\begin{array}{l}\text { Regulation of nutrients in } \\
\text { the soil and water }\end{array}$ & $\begin{array}{c}\text { Reduction of organic load and nutrients of } \\
\text { waste after treatment through anaerobic } \\
\text { digestion }\end{array}$ & $\begin{array}{l}\text { Concentration of nutritious } \\
\text { elements }(\mathrm{C}, \mathrm{N}, \mathrm{P}, \mathrm{K}) \text { in digestate }\end{array}$ \\
\hline $\begin{array}{l}\text { Regulation of global } \\
\text { climate }\end{array}$ & $\begin{array}{c}\text { Reduction in the emission of greenhouse } \\
\text { effect gases }\end{array}$ & $\begin{array}{l}\text { Carbon capture } \\
\text { from emissions of } \mathrm{CH}_{4}, \mathrm{CO}_{2} \text {, } \\
\mathrm{N}_{2} \mathrm{O}\left(\mathrm{t} \mathrm{C} \text { year }^{-1}\right)\end{array}$ \\
\hline
\end{tabular}

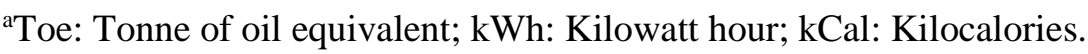

\subsection{Biogas contributions to the ecosystem and human well-being}

Biogas as a provisioning ecosystem service is considered an energy product, originated from the treatment of animal waste through anaerobic digestion, which can be used to generate electricity and heat or purified and used in the transportation sector. To exemplify the energetic use of the biogas considering the herd of pigs that has the potential to produce biogas, some estimates that show the importance of biogas for general human well-being were calculated, as well as the environmental benefits for the ecosystems. The number of pigs in Brazil in 2016 was 39.95 million head and the Southern region held $49.9 \%$ of this total (IBGE, 2015). The estimated production of excrement, the potential of biogas production and the reduction in the emissions of methane $\left(\mathrm{CH}_{4}\right)^{1}$ through the anaerobic digestion regarding pigs from the southern region are found in Table 3.

Table 3. Estimate of the production potential of excrement, biogas and reduction in emissions of methane by pigs from the Southern region.

\begin{tabular}{lccc}
\hline & $\begin{array}{c}\text { Production of excrement } \\
\left(\mathrm{m}^{3} \text { year }^{-1}\right)\end{array}$ & $\begin{array}{c}\text { Production of biogas } \\
\left(\mathrm{m}^{3} \text { year }^{-1}\right)\end{array}$ & $\begin{array}{c}\text { Reduction in emissions } \\
\left(\mathrm{tCO}_{2} \mathrm{e} \mathrm{year}^{-1}\right)\end{array}$ \\
\hline Southern Region & $46,076,114$ & $979,707,211$ & $7,443,619$ \\
\hline
\end{tabular}

\footnotetext{
${ }^{1}$ Calculations on the estimate of production of excrement based on the production of $0.007 \mathrm{~m} 3 /$ day (Oliveira, 1993); and for the calculation of the estimates of biogas production and emissions of methane, the methodology established by the Intergovernmental Panel On Climate Change (IPCC) contained in the guidelines of UNFCCC (United Nations Framework Convention on Climate Change), and the reference value of the Guidelines for National Greenhouse Gas Inventories (IPCC, 2006) was used.
} 
From the data contained in Table 3 and considering the energy equity of the cubic meter of biogas described by Barreira (2011), the energy equity of pigs from the Southern region was estimated. The biogas estimated in equity with gasoline ( $0.613 \mathrm{~L}$ of gasoline) would generate about 1,645,371 L per day, which would permit, for example, traveling about 23,035,194 km per day, considering a popular car (14 $\mathrm{km} \mathrm{L}^{-1}$ of gasoline). It would be possible to replace cooking gas (liquefied petroleum gas) with biogas (0.454 L of cooking gas) which would generate $1,218 \mathrm{~m}^{3}$ of gas per day. Comparing with electric energy $(1.43 \mathrm{kWh})$ the biogas could meet the energy demand of 659,223 homes in the Southern region, considering the average consumption of $177.1 \mathrm{kWh}$ of electric energy per month, according to the Empresa de Pesquisa Energética in 2016 (EPE, 2017).

As a regulating service, biogas is especially related to the reduction of the emission of greenhouse gases like $\mathrm{CH}_{4}, \mathrm{CO}_{2}$ (carbon dioxide) and $\mathrm{N}_{2} \mathrm{O}$ (nitrous oxide), reduction of odors and organic load and of some nutrients present in the waste. The odors are an important loss to the environment for people who live near pig production units, affecting public health due to the diffusion of diseases and odors to the nearby population (Orzi et al., 2015). However, anaerobic digestion reduces the atmospheric emissions of methane and odorous compounds (Van Horn et al., 1994; Orzi et al., 2010).

The digestate, is usually a low dry matter product, rich in plant nutrients and can be recycled as a high quality organic soil fertiliser, if the content of heavy metals and organic pollutants makes it suitable for this. The use of digestate originated from the anaerobic digestion of animal waste, in relation to the use of waste in natura, reduces or eliminates completely the energy and economic costs of production of fertilizers. It makes exportation, redistribution and recycling of excess waste possible (Holm-Nielsen et al., 2009). The nutritional value of waste has been especially linked to the presence of N, P and K (potassium), but the need for nutrients depends on the soil and on the characteristics of the culture and the proportion of nutrients available in the waste or digestate may not be adequate, resulting in excess or lack of these nutrients (Aguirre-Villegas et al., 2014). The digestate presents high concentrations of $\mathrm{N}$ and P, as well as C and K (Appels et al., 2008; Schievano et al., 2009) and when applied to the soil improves fertility and increases the microbial community (Owamah et al., 2014).

In livestock production, $\mathrm{N}_{2} \mathrm{O}, \mathrm{CH}_{4}$ and $\mathrm{CO}_{2}$ are the most important contributors to global warming (Olesen et al.,2006), depending on how they are produced (solid, liquid) and managed (collection, storage, arrangement). Anaerobic digestion through biodigesters is a promising practice to mitigate the emission of greenhouse effect gases from the collected waste, with potential to decrease odor and loads of pathogenic bacteria of waste when compared to direct application in the soil without treatment (Montes et al., 2013) and, when used correctly, anaerobic digesters are a source of renewable energy in the form of biogas, which is from 60 to $80 \% \mathrm{CH}_{4}$, depending on the substrate and conditions of operation (Holm-Nielsen et al., 2009; Montes et al., 2013). Therefore, production of biogas is a mitigation strategy that has significant potential to capture and destroy most $\mathrm{CH}_{4}$ from the waste and generate renewable energy, reducing emissions of greenhouse effect gases, NOx, hydrocarbons and particles (Montes et al., 2013).

Table 3 gives an example of the reduction of greenhouse gases emissions from the excrement. In this context, the reduction of the emission of greenhouse gases, such as methane, occurs by treating the excrement through anaerobic digestion in biodigesters and with biogas combustion, which is converted into $\mathrm{CO}_{2}$, preventing, consequently, emissions of methane into the environment.

The generation of biogas from anaerobic digestion of biomass is a technology that can produce sustainable energy and also help in the management of waste. Thus, it has potential to assist in the transition of energy based in fossil fuels to renewable energy, especially because of the availability of residual biomass. It can also contribute to strategies of sustainable 
development in rural areas. The capacity of biogas to decrease pollutant load through use of residues, regulate ecosystem service, and improve the efficiency of the energy supply infrastructure, like the provisioning ecosystem service, are arguments in favor of the development of biogas. For this reason, it is possible to say that the production of biogas has less trade-offs than other renewable sources, as trade-offs play a crucial role in the interpretation of sustainability of developments related to human well-being (Liu et al., 2015; Wu, 2013).

\section{CONCLUSION}

The environmental problems created by intensive systems of livestock production derive mainly from their local concentration, but also from the technology and the management system adopted. The high density of animals is always followed by the production of surplus excrement, which leads to pressures on the ecosystem and generates impacts on the environment, mainly through the volume and composition of the excrement when improperly discarded. In view of the lack of economic and environmental incentives to treat the excrement efficiently and to internalize the environmental costs, more excrement is produced than can be assimilated, which increases the risks associated with water-, soil- and air pollution. However, this waste constitutes a residual biomass available to generate energy, exported or used by the very own system of production or another system of the property, also using the digestate as a fertilizer. The use of residual biomass to produce biogas can be considered sustainable because it does not use direct resources from ecosystem services, and supplies regulating and provisioning services.

Besides the relevance for the understanding of the impacts of the decisions and actions about the environment, the understanding of biogas in the ecosystem services is interesting in order to understand how the environment is affected. In addition, the framework of the biogas in the ecosystem services systematically shows the contributions to the ecosystem and to the human well-being. These facts can help raise awareness of the political decision-makers and farmers regarding the importance of excrement treatment and the generation of renewable energy through biogas.

\section{REFERENCES}

AGUIRRE-VILLEGAS, H. A.; LARSON, R.; REINEMANN, D. J. From waste-to-worth: energy, emissions, and nutrient implications of manure processing pathways. Biofuels, Bioproducts and Biorefining, v. 8, n. 6, p. 770-793, 2014. https://dx.doi.org/10.1002/bbb.1496

APPELS, L.; BAEYENS, J.; DEGREVE, J.; DEWIL, R. Principles and potential of the anaerobic digestion of waste-activated sludge. Progress in Energy and Combustion Science, v. 34, n. 6, p. 755-781, 2008. https://dx.doi.org/10.1016/j.pecs.2008.06.002

ARODUDU, O. T.; VOINOV, A.; VAN DUREN, I. Assessing bioenergy potentials in rural

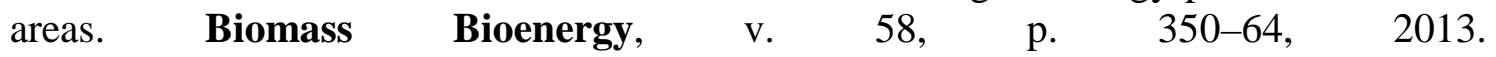
https://dx.doi.org/10.1016/j.biombioe.2013.07.020

BARREIRA, P. Biodigestores: energia, fertilidade e saneamento para a zona rural. 3. ed. São Paulo: Ícone, 2011. 106 p.

BAUMGÄRTNER, S.; DYCKHOFF, H.; FABER, M.; PROOPS, J.; SCHILLER, J. The concept of joint production and ecological economics. Ecological Economics, v. 36, p. 365-372, 2001. https://dx.doi.org/10.1016/S0921-8009(00)00260-3 
BRABAND, D.; GEIER, U.; KÖPKE, U. Bio-resource evaluation within agri-environmental assessment tools in different European countries. Agriculture, Ecosystems \& Environment, v. 98, n. 1-3, p. 423-434, 2003. https://dx.doi.org/10.1016/S01678809(03)00101-4

BUHRING, G. M. B.; SILVEIRA, V. C. P. O biogás e a produção de suínos do sul do Brasil. Revista Brasileira de Energia Renováveis, v. 5, p. 222-237, 2016. https://dx.doi.org/10.5380/rber.v5i2.43546

BURKHARD, B.; DE GROOT, R. S.; COSTANZA, R.; SEPPELT, R.; JØRGENSEN, S. E.; POTSCHIN, M. Solutions for sustaining natural capital and ecosystem services. $\begin{array}{llllll}\text { Ecological Indicators, } & \text { v. } & \text { 21, } & \text { p. } & 1-6,\end{array}$ https://dx.doi.org/10.1016/j.ecolind.2012.03.008

CHERUBINI, F.; STRØMMAN, A. H. Life cycle assessment of bioenergy systems: state of the art and future challenges. Bioresource Technology, v. 102, n. 2, p. 437-451, 2011. https://dx.doi.org/10.1016/j.biortech.2010.08.010

COSTANZA, R.; D’ARGE, R.; DE GROOT, R. S.; FARBER, S.; GRASSO, M.; HANNON, B. et al. The value of the world's ecosystem services and natural capital. Nature, v. 387, p. 253-260, 1997. https://dx.doi.org/10.1038/387253a0

EMPRESA DE PESQUISA ENERGÉTICA. Anuário Estatístico de Energia Elétrica 2017 ano base 2016. Brasília: MME, 2017. Available: https://goo.gl/jFJpkX Accessed: 01 March 2018.

FERNANDEZ-LOPEZ, M.; LÓPEZ-GONZÁLEZ, D.; PUIG-GAMERO, M.; VALVERDE, J.; SANCHEZ-SILVA, L. CO2 gasification of dairy and swine manure: A life cycle assessment approach. Renewable Energy, v. 95, p. 552-560, 2016. https://dx.doi.org/10.1016/j.renene.2016.04.056

FISHER, B.; TURNER, R. K.; MORLING, P. Defining and classifying ecosystem services for decision making. Ecological Economics, v. 68, n. 3, p. 643-653, 2009. https://dx.doi.org/10.1016/j.ecolecon.2008.09.014

GISSI, G.; GAGLIO, M.; REHO, M. Sustainable energy potential from biomass through ecosystem services trade-off analysis: The case of the Province of Rovigo (Northern $\begin{array}{lllllll}\text { Italy). } & \text { Ecosystem } & \text { Services, } & \text { v. }\end{array}$ https://dx.doi.org/10.1016/j.ecoser.2016.01.004

HAINES-YOUNG, R.; POTSCHIN, M. Common International Classification of Ecosystem Services (CICES): consultation on version 4, August-December 2012. Nottingham, University of Nottingham, 2013. Available: https://goo.gl/9hDxYM . Accessed: 05 Dec. 2016.

HAINES-YOUNG, R.; POTSCHIN, M. The links between biodiversity, ecosystem services and human well-being. In: RAFFAELLI, D.; FRID, C. (Eds.). Ecosystem Ecology: A New Synthesis. Cambridge: CUP, 2010. p. 110-139.

HASTIK, R.; BASSO, S.; GEITNER, C.; HAIDA, C.; POLJANEC, A.; PORTACCIO, A. et al. Renewable energies and ecosystem service impacts. Renewable and Sustainable Energy Reviews, v. 48, p. 608-623, 2015. https://dx.doi.org/10.1016/j.rser.2015.04.004

HOLM-NIELSEN, J. B.; AL SEADI, T.; OLESKOWICZ-POPIEL, P. The future of anaerobic digestion and biogas utilization. Bioresource Technology, v. 100, n. 22, p. 5478-5484, 2009. https://dx.doi.org/10.1016/j.biortech.2008.12.046 
INSTITUTO BRASILEIRO DE GEOGRAFIA E ESTATÍSTICA. Produção da pecuária municipal. Rio de Janeiro, 2015. 51 p.

INSTITUTO DE PESQUISA ECONÔMICA APLICADA. Diagnóstico dos resíduos orgânicos do setor agrossilvopastoril e agroindústrias associadas. Brasília: IPEA, 2012.

INTERGOVERNMENTAL PANEL ON CLIMATE CHANGE. Guidelines for National Greenhouse Gas Inventories. Chapter 10: Emissions from Livestock and Manure Management. Volume 4: Agriculture, Forestry and Other Land Use. Geneva, 2006. 87p.

JACKSON, A. L. R. Renewable energy vs. biodiversity: policy conflicts and the future of nature conservation. Global Environmental Change, v. 21, n. 4, p. 1195-208, 2011. https://dx.doi.org/10.1016/j.gloenvcha.2011.07.001

JUNFENG, L.; RUNQING, H. Sustainable biomass production for energy in China. Biomass Bioenergy, v. 25, p. 483-99, 2003. https://dx.doi.org/10.1016/S0961-9534(03)00086-2

KANDZIORA, M.; BURKHARD, B.; MÜLLER, F. Interactions of ecosystem properties, ecosystem integrity and ecosystem service indicators - A theoretical matrix exercise. $\begin{array}{llllll}\text { Ecological Indicators, } & \text { v. } & 28, & \text { p. }\end{array}$ https://dx.doi.org/10.1016/j.ecolind.2012.09.006

LAYKE, C.; MAPENDEMBE, A.; BROWN, C.; WALPOLE, M.; WINN, J. Indicators from the global and sub-global Millennium Ecosystem Assessments: an analysis and next steps. Ecological Indicators, v. 17, p. 77-87, 2012. https://dx.doi.org/10.1016/j.ecolind.2011.04.025

LIU, J.; MOONEY, H.; HULL, V.; DAVIS, S. J.; GASKELL, J.; HERTEL, T. et al. Systems integration for global sustainability. Science, v. 347, p. 963-972, 2015. https://dx.doi.org/10.1126/science.1258832

LOYON, L. Overview of manure treatment in France. Waste Management, v. 61, p. 516-520, 2017. https://dx.doi.org/10.1016/j.wasman.2016.11.040

MAES, J.; LIQUETE, C.; TELLER, A. et al. An indicator framework for assessing ecosystem services in support of the EU Biodiversity Strategy to 2020. Ecosystem Services, v. 17, p. 14-23, 2016. https://dx.doi.org/10.1016/j.ecoser.2015.10.023

MATA-ALVAREZ, J.; MACE, S.; LLABRES, P. Anaerobic digestion of solid wastes. An overview of research achievements and perspectives. Bioresource Technology, v. 74, n. 1, p. 3-16, 2000. https://dx.doi.org/10.1016/S0960-8524(00)00023-7

MCBRIDE, A. C.; DALE, V. H.; BASKARAN, L. M.; DOWNING, M. E.; EATON, L. M.; EFROYMSON, R. A. et al. Indicators to support environmental sustainability of bioenergy systems. Ecological Indicators, v. 11, n. 5, p. 1277-1289, 2011. https://dx.doi.org/10.1016/j.ecolind.2011.01.010

MILLNER, P.; INGRAM, D.; MULBRY, W.; ARIKAN, O.A. Pathogen reduction in minimally managed composting of bovine manure. Waste Management, v. 34, n. 11, p. 1992-1999, 2014. https://dx.doi.org/10.1016/j.wasman.2014.07.021

MONTES, F.; MEINEN, R.; DELL, C.; ROTZ, A.; HRISTOV, A. N.; OH, J. et al. Special topics-Mitigation of methane and nitrous oxide emissions from animal operations: II. A review of manure management mitigation options. Journal of Animal Science, n. 91, v. 11, p. 5070-5094, 2013. https://dx.doi.org/10.2527/jas.2013-6584 
MÜLLER, F.; BURKHARD, B. The indicator side of ecosystem services. Ecosystem Services, v. 1, n. 1, p. 26-30, 2012. https://dx.doi.org/10.1016/j.ecoser.2012.06.001

OLESEN, J. E.; SCHELDE, K.; WEISKE, A.; WEISBJERG, M. R.; ASMAN, W. A. H; DJURHUUS, J. Modelling greenhouse gas emissions from European conventional and organic dairy farms. Agricultural, Ecosystems \& Environment, v. 112, n. 2-3, p. 207220, 2006. https://dx.doi.org/10.1016/j.agee.2005.08.022

OLIVEIRA, P. A. V. Manual de manejo e utilização dos dejetos de suínos. Concórdia: EMBRAPA-CNPSA, 1993.188p. (EMBRAPA - CNPSA. Documentos, 27).

OLSON-HAZBOUN, S. K.; KRANNICH, R. S.; ROBERTSON, P. G. Public views on renewable energy in the Rocky Mountain region of the United States: Distinct attitudes, exposure and other key predictors of wind energy. Energy Research \& Social Science, v. 21, p. 1-13, 2016. https://dx.doi.org/10.1016/j.erss.2016.07.002

ORZI, V.; CADENA, E.; D'IMPORZANO, G.; ARTOLA, A.; DAVOLI, E.; CRIVELLI, M. et al. Potential odour emission measurement in organic fraction of municipal solid waste during anaerobic digestion: relationship with process and biological stability parameters.

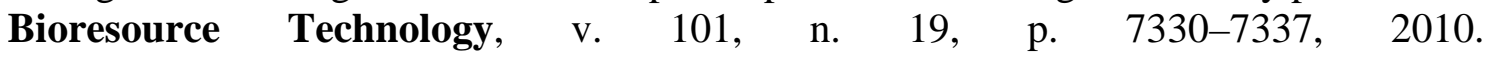
https://dx.doi.org/10.1016/j.biortech.2010.04.098

ORZI, V.; SCAGLIA, B.; LONATI, S.; RIVA, C.; BOCCASILE, G.; ALBORALI, G. L. et al. The role of biological processes in reducing both odour impact and pathogen content during mesophilic anaerobic digestion. Science of The Total Environment, v. 526, p. 116-126, 2015. https://dx.doi.org/10.1016/j.scitotenv.2015.04.038

OUDART, D.; ROBIN, P.; PAILLAT, J.-M.; PAUL, E. Modelling nitrogen and carbon interactions in composting of animal manure in naturally aerated piles. Waste $\begin{array}{lllll}\text { Management, } & \text { v. } & 46, & \text { p. } & \text { 588-598, }\end{array}$ https://dx.doi.org/10.1016/j.wasman.2015.07.044

OWAMAH, H. I.; DAHUNSI, S. O.; ORANUSI, U. S.; ALFA, M. I. Fertilizer and sanitary quality of digestate biofertilizer from the codigestion of food waste and human excreta. $\begin{array}{llllllll}\text { Waste Management, } & \text { v. 34, n. 4, p. }\end{array}$ https://dx.doi.org/10.1016/j.wasman.2014.01.017

QIAO, W.; YAN, X.; YE, J.; SUN, Y.; WANG, W.; ZHANG, Z. Evolution of biogas production from different biomass wastes with/without hydrothermal pretreatment. Renewable Energy, v. 36, n. 12, p. 3313-3318, 2011. https://dx.doi.org/10.1016/j.renene.2011.05.002

REYERS, B.; BIDOGLIO, G.; O’FARRELL, P.; SCHUTYSER, F.; DHAR, U.; GUNDIMEDA, H. et al. Measuring biophysical quantities and the use of indicators. In: KUMAR, P. (Ed.). The Economics of Ecosystems and Biodiversity: Ecological and Economic Foundations. Earthscan: Routledge, 2010. p 113-147.

SCHIEVANO, A.; D’IMPORZANO, G.; ADANI, F. Substituting energy crops with organic wastes and agro-industrial residues for biogas production. Renewable and Sustainable $\begin{array}{lllllll}\text { Energy Reviews, } & \text { v. } & \text { 9, n. } & \text { 8, } & \text { p. }\end{array}$ https://dx.doi.org/10.1016/j.jenvman.2009.01.013

SILVEIRA, V. C. P.; GONZALEZ, J. A.; FONSECA, E. L. Land use changes after the period commodities rising price in the Rio Grande do Sul State, Brazil. Ciência Rural, v. 47, n. 4, e20160647, 2017. https://dx.doi.org/10.1590/0103-8478cr20160647 
STEFFEN, W.; RICHARDSON, K.; ROCKSTRÖM, J. et al. Planetary boundaries: guiding human development on a changing planet. Science, v. 347, n. 6223, p. 1259855, 2015. https://dx.doi.org/10.1126/science.1259855

SUMMERS, J. K.; SMITH, L. M.; CASE, J. L.; LINTHURST, R. A. A review of the elements of human well-being with an emphasis on the contribution of ecosystem services. Ambio, v. 41, n. 4, p. 327-340, 2012. https://dx.doi.org/10.1007/s13280-012-0256-7

SWINTON, S. M.; LUPI, F.; ROBERTSON, G. P.; HAMILTON, S. K. Ecosystem services and agriculture: cultivating agricultural ecosystems for diverse benefits. Ecological $\begin{array}{lllllll}\text { Economics, } & \text { v. } 64, & \text { n. } & \text { 2, } & \text { p. }\end{array}$ https://dx.doi.org/10.1016/j.ecolecon.2007.09.020

TUKKER, A.; JANSEN, B. Environmental impacts of products: a detailed review of studies. Journal of Industrial Ecology, v. 10, n. 3, p. 159-182, 2006. https://dx.doi.org/10.1162/jiec.2006.10.3.159

VAN HORN, H. H.; WILKIE, A. C.; POWERS, W. J.; NORDSTEDT, R. A. Components of dairy manure management systems. Journal Dairy Science, v. 77, n. 7, p. 2008-30, 1994. https://dx.doi.org/10.3168/jds.S0022-0302(94)77147-2

WHALEN, J.; XU, C.; SHEN, F.; KUMAR, A.; EKLUND, M.; YAN, J. Sustainable biofuel production from forestry, agricultural and waste biomass feedstocks. Applied Energy, v. 198, p. 281-283, 2017. https://dx.doi.org/10.1016/j.apenergy.2017.05.079

WU, J. Landscape sustainability science: ecosystem services and human well-being in changing landscapes. Landscape Ecology, v. 28, n. 26, p. 999-1023, 2013. https://dx.doi.org/10.1007/s10980-013-9894-9 